\title{
CONTRIBUTION TO THE DEVELOPMENT OF THE DIRECT AND INDIRECT COSTS REDUCTION MODEL (DICRM-8) IN MANUFACTURING COMPANIES
}

\author{
Berislav Bolfek ${ }^{11}$
}

UDC / UDK: 657.471.1

JEL classification / JEL klasifikacija: L23, L60, L73

DOI: https://doi.org/10.22598/pi-be/2021.15.1.81

Scientific review / Pregledni znanstveni rad

Received / Primljeno: December 12, 2020 / 12. prosinca 2020.

Accepted for publishing / Prihvaćeno za tisak: April 12, 2021 / 12. travnja 2021.

\section{Summary}

There are numerous methods described in the literature that explain how to reduction certain types of costs. Most of the methods mentioned in the literature do not list specific cost reduction measures and activities. The problem in manufacturing companies arises when the actual cost price of an individual product obtained by calculating a work order exceeds the planned price of that product. The goal of the research is to find one of the ways to solve the problem by reduction direct and indirect costs. The methodology is based on the development and establishment of the Direct and Indirect Costs Reduction Model (DICRM-8) in manufacturing companies, which consists of eight interconnected steps. The test results show the full functionality of the model, which enabled the comparison of planned, incurred and projected cost prices in one place, as well as calculating the total amount of cost reduction for all work orders. The key results illustrate the use of different measures and activities to reduction costs in the case of wood industry. This research contributes to the development of models for reduction direct and indirect costs in manufacturing companies.

Keywords: direct costs; indirect costs; cost reduction; manufacturing companies; DICRM-8.

\section{INTRODUCTION}

Management and managers have an ongoing task to achieve the planned business policy goals with the lowest possible costs and without long-term negative consequences

${ }^{11}$ Berislav Bolfek, PhD, Associate Professor, University of Zadar, Department of Economics, Croatia, E-mail: bbolfek@unizd.hr 
on the business result and competitive position in the market. This primarily relates to manufacturing companies, which are facing an increasing competition due to growing internationalization and globalization in the domestic and global markets. As part of the Cost Management Concept, which includes estimate, planning, budgeting, controlling and analyzing of costs, cost reduction also takes a special place. Active cost management involves a constant and systematic seeking of opportunities to cost reduction and a consistent implementation of cost reduction measures and activities. The final result of the cost reduction process should be achieved by increasing the profit at the end of the year, which was not caused by the growth in sales prices. In this way, the company also achieves a better position in the market compared to its competitors, because it can also reduction the sales price of its products. The companies that produce several different types of products at the same time need to provide, through their accounting, the data and information on production costs for each individual product. Monitoring production costs up to the level of each individual product is possible by using a work order system (Belak, 2009). The work order serves to record the resources used to produce a certain volume of a particular product. In this way, all direct incurred costs (base material, auxiliary material, cooperation and manufacturing) in the manufacturing of a particular product are collected. When calculating a work order, other costs and/or indirect costs (other materials and services, overhead, electricity, heat, water, depreciation, administration and sales costs) are allocated through selected methods for allocating indirect costs to all work orders. The procedure of all work orders calculation through which the cost price for a particular work order or a product is calculated is done by summing the direct and indirect incurred costs.

The problem arises when the achieved cost price for an individual product obtained by calculating a work order deviates from the planned cost price in the projected calculation for that product. Therefore, solving this problem is the subject of the research in this paper. In order to solve the problem, it is necessary to analyze the direct and indirect incurred costs by comparing them with the planned ones. The result of this analysis should present what types of direct and indirect costs need to be reduction and what cost reduction measures and activities should be implemented to achieve the planned cost price of each product.

One of the ways to solve the described problem is to develop the Direct and Indirect Costs Reduction Model DICRM-8 in manufacturing companies related to the implementation of the following activities: comparison of planned and subsequent calculation, reduction of direct and indirect costs, forecasting cost prices for all work orders; comparing planned, achieved and forecasted cost price and calculating the total volume of cost reduction by all work orders.

It is still necessary to define the following terms such as cost, outlay and expense. Costs represent the values of spent goods caused by the production of new goods. Costs in a broader sense include all elements of the cost price, ie all transferred and part of the newly created value. Outlays are cash payments for received material values and other services. Expenses are a broader term than costs and outlays. They include costs and outlays that result from the acquisition of some equivalent (in the tangible and intangible form), but these are also some payments for which companies do not receive any 
equivalent. Expense is decreased in economic benefits during the accounting period in the form of outflows or diminutions of assets or increases of liabilities that result in a decrease in equity.

The paper consists of six chapters in total, so following the introductory chapter there is the second chapter describing a review of the literature related to the area of cost reduction. The third chapter provides a methodology for developing the Direct and Indirect Costs Reduction Model in manufacturing companies. The fourth chapter provides a description of testing and an analysis of the model in the previous chapter. Chapter 5 describes the results obtained by testing the Direct and Indirect Costs Reduction Model in manufacturing companies. The last chapter provides the final considerations with respect to proving the hypothesis and recommendations for further research.

\section{LITERATURE REVIEW}

The cost reduction process in the literature has been largely described: from manufacturing, through services to healthcare. However, there are very few research papers that describe individual cost reduction models, especially those relating to reduction direct and indirect costs in manufacturing companies.

In one of the first papers on cost reduction in industry (Monden and Lee, 1993) claim: Japanese car manufacturers employ Kaizen costing to ensure continuous improvement activities. This cost accounting method is an essential component of the cost reduction process in the manufacturing phase and even in the entire product design development production cycle when used in combination with target costing. Unlike the standard cost system whose aim is to meet the cost standards, the Kaizen costing's target is to keep the actual costs below the standard costs. The advantage of this approach lies in its close link with the entire company's profit planning process.

The next most recent paper in the field (Dubynina 2020) deals with the problems of cost formation as the main factor in the enterprise functioning and production efficiency. The issues of classification and different grouping of production costs of the enterprise to identify reserves and ways of the cost reduction are investigated in the article. The main reserves for the production costs reduction are considered. The focus is made on the certainty and the application in practice of the more significant reserves to cost reduction of industrial products, which will influence the competitiveness of this type of the goods and result in its being break-even on the market, or even better - it's being cost-effective at all stages of the production cycle.

Effective long-term cost reduction is a continuous activity that must be a strategic priority. Unlike traditional cost reduction focused on rapid cost reduction due to immediate crises, strategic cost reduction must be part of a competitive strategy that integrates the strategies for managing technology and human resources and provides a long-term approach to cost reduction. The long-term competitive cost benefit depends on establishing a culture of continuous improvement in quality, time and costs through innovation (Shields, et al. 1992). 
In their paper on cost reduction in manufacturing sector, Barbole, et al. (2013) focus on the impact of cost control and cost reduction in an existing production program and state that, in manufacturing companies, the main element of cost is the cost of materials. The authors explain the techniques for cost reduction and cost control used at different stages of production and their impact on material costs. Furthermore, in times of difficult business climate when sale is dropping and becomes uncertain, each manufacturing company should adopt cost reduction strategies as soon as possible to avoid potential job losses.

According to Spence (1986), companies compete against time in many markets by spending resources to reduction their costs. Sometimes cost reduction investments have a direct impact on costs. In many cases, they take the form of developing new products that are sold at a lower price to customers. Therefore, product development can have the same ultimate effect as a direct cost reduction.

The impact of reduction unit costs on gross profit is analyzed by Dahan, et al. (2011) who pose a question: how important are the unit production costs in the design and development of new products. Their knowledge regarding the effect on cost reduction is contrary to intuitions of many managers. The authors confirm that early and effective efforts to cost reduction can increase the chances of success of a new product to a greater extent than it is commonly believed and that the benefits of reduction unit costs justify significant investment in "smarter" design during the development of new products.

In his following paper, Pereira (2001) seeks to reconcile two opposing views on how market power affects incentives in investing in cost reduction. He proves that the relationship between market power and cost reduction depends on the context in the sense that both market power and investment in cost reduction are endogenous variables, and the shifts in different parameters encourage them to differ from each other in another way, i.e. in opposite directions or in the same direction.

Cost reduction and quality improvement in SMEs are described in the paper of Soundararajan, et al. (2019). The authors cite the Six Sigma Methodology as a tool for significant cost reduction and quality improvement on the example of manufacturing companies.

In their paper, Todorut, et al. (2016) point to the need sustainably cost reduction in metallurgical industry by applying the tools and concepts of Lean Management, which in metallurgical production processes lead to an increase in competitiveness of companies in the global market. The paper points out that Lean Management is a new way of thinking, adaption to changes, waste minimization and continuous improvement, that results in the sustainable development of companies in metallurgical industry.

Cost reduction in printing industry is being addressed by Moreira et al. (2018), who in their paper describe the process of reduction the use of toxic products and general costs in the offset printing process, as well as increasing productivity in printing industry.

Susto, et al. (2018) describe cost reduction in semiconductor manufacturing where the metrology as an expensive non-value added operation significantly affects the time of the production cycle. The authors state that reduction metrology is still a major goal in semiconductor manufacturing initiatives. They compare data-driven spatial dynamic sampling methodologies. Such strategies aim to reduction the number of points 
that need to be measured while maintaining an acceptable level of accuracy, and thus reduction production costs.

In their paper, Castellano, et al. (2017) explore a model of periodic stock review under stochastic demand where order costs and production time are controlled. In the model, the authors imply an imperfect manufacturing process, the quality of which can be enhanced by investments, including a price discount to motivate buyers to wait for orders. The goal is to determine the review period, the ordering cost, the level of quality, price discounts and the length of production time that reduction in the long run the expected total cost per unit of time.

Huang (2010) developed an integrated stock model to determine the optimal policy under conditions of reduction order processing costs and allowable payment delays. In the mentioned model, both the supplier and the buyer participate in reduction the ordering costs by applying information technologies. Order processing costs can be reduction by certain expenditures and will affect decisions concerning production batch size. At the same time, the existence of a loan period serves to reduction the cost of keeping stock for the buyer as it reductions the amount of capital invested in stock over the life of the loan period.

In the following paper, the authors Kuo-Ren, et al. (2013) modified the integrated stock model from the previous paper (Huang, 2010) by supplementing deficiencies and mitigating the assumption that customer revenues are always less or equal to the interests charged. In addition, they treated the total number of shipments in one production batch size as a decision variable for the supplier, further reduction the overall annual cost for the supplier as well as the integrated solution. Thus, they have acquired the necessary and sufficient conditions to reach the optimum solution and have established a term of discrimination to determine whether the buyer's reimbursement cycle time is less than the allowed delay period or not.

Another model that deals with reduction stock costs was developed by Jauhari, et al. (2017), which goal is to simultaneously optimize the stock review period, the production rate, ordering costs and the number of deliveries, thus minimizing total costs.

In their paper, Salim and Johansson, (2018) to study which aspects are considered when automation decisions concerning manufacturing are made in the wood products industry. The findings demonstrate that the considered aspects regarding automation are identified in the following decision areas of manufacturing: Capacity, Facility, Process technology, and Quality management. The wood products industry further has been described as slow in adapting efficiency increasing activities. This implies a need for activities, such as investments in automation, in the Swedish wood products industry to increase the refinement level of the products and increase efficiency.

In the following paper, the authors Johnsson, et al. (2019) investigate applied and potentially viable energy key performance indicators. Suggestions for improving energy key performance indicators within the wood industry include separating figures for different wood varieties and different end-products and distinguishing between different drying kiln technologies. Finally, the paper presents the major energy-saving and carbon mitigating measures by constructing conservation supply curves and marginal abatement cost curves. The energy-saving potential found in the studied companies 
indicates that significant improvements might be achieved throughout the Swedish wood industry.

In their paper, Arminen, et al. (2012) analyse econometrically the Finnish inventory to value-added ratios (i.e., inventory intensities) within manufacturing and two subcategories, the wood and paper industry and manufacture of electrical products. In addition to revealing the statistically significant breakpoints in the inventory intensity, they estimate the numbers, timings and magnitudes of the structural breaks. After determining the breakpoints, they connect them to the transaction, buffering and speculative motives for holding inventories. The properties of the breakpoints observed suggest that the motives continue to play a role in modern small open economies and, therefore, they can be utilised by managers when trying to forecast the behaviour of inventories.

If we recapitulate the results of the aforementioned research papers, it can be concluded that the described cost reduction process can be applied to different industries, noting that, as a rule, it is always a matter of reduction only one type of cost. However, this paper differs from the existing research papers, because a model for reduction all types of costs in manufacturing companies has been developed. It means that the reduction of direct costs and the reduction of indirect costs are separately implemented in the mentioned model. Development of the Direct and Indirect Costs Reduction Model in manufacturing companies will be presented and quantified in the following methodological section of this paper.

\section{MODEL DEVELOPMENT METHODOLOGY}

The development of the Direct and Indirect Costs Reduction Model (DICRM-8) in manufacturing companies starts from the fact that the entire process of data transformation in the model takes place in eight interconnected steps. The first step relates to the entering of basic company information, while in the second step data from planned calculations are entered. The third step contains data on direct costs, while the fourth step includes data on indirect costs that are allocated to facilities in the first phase and to work orders in the second phase. In the fifth step, direct costs are reduction by selecting certain measures and activities, while in the sixth step, indirect costs are reduction. The calculation of the work order is shown in the seventh step, while the eighth last step refers to the calculation recapitulation of all work orders (Chart 1).

The proposed model will test the following hypothesis:

H1: By implementing the Direct and Indirect Costs Reduction Model (DICRM8), it is possible to efficiently manage direct and indirect costs in manufacturing companies.

Every company that intends to implement a cost reduction process by using the Direct and Indirect Costs Reduction Model DICRM-8 in manufacturing companies should meet the following minimum requirements: 
- Manufacturing activity,

- Batch or mass production,

- Production planning (elaboration of planned calculations),

- Monitoring production through work orders,

- IT support to the production and financial accounting.

Below is a description of all the steps in Direct and Indirect Costs Reduction Model in manufacturing companies that will be tested by using Microsoft Excel.

Chart 1. Steps in the model DICRM-8

\begin{tabular}{|c|}
\hline Direct and Indirect Costs Reduction Model DICRM-8 \\
\hline STEP 1: Basic company information \\
\hline STEP 2: Planned calculation \\
\hline STEP 3: Direct incurred costs \\
\hline STEP 4: Indirect incurred costs \\
\hline STEP 5: Reduction of direct costs \\
\hline STEP 6: Reduction of indirect costs \\
\hline STEP 7: Work order calculation \\
\hline PTEP 8: Work orders calculation recapitulation \\
\hline
\end{tabular}

Source: created by the author

\subsection{Basic company information (Step 1)}

In the first step, the user should enter the following information: date, name and headquarters of the company, the time period for which work orders are calculated, and the total number of work orders (planned calculations), then the number and name of the facility (number of employees per facility) and finally the sales price per unit of product (for all work orders). In case the company does not have facilities, the user will leave this blank. All the information required for the model to function is entered once in one place and automatically captured in the following steps. 


\subsection{Planned calculation (Step 2)}

The second step relates to the planned calculation, so the user here enters the following data: number of facility, product name and unit of measure, and direct and indirect costs per individual categories. For individual cost categories, the user should enter: unit of measure, quantity and unit price, while Excel calculates the total cost of each cost category, and finally the cost of production and the cost price. The process is repeated as many times as there are products, i.e. planned calculations.

\subsection{Direct incurred costs (Step 3)}

In the third step, the user enters the following data on incurred direct costs for each work order: the quantity of items produced, the costs of base and auxiliary materials, the costs of cooperation and manufacturing and other costs. After entering all the data, Excel calculates the total direct incurred costs per individual work orders as well as the total costs for all work orders.

\subsection{Indirect incurred costs (Step 4)}

In the fourth step, the user enters incurred indirect costs for the entire company and selects different methods for allocating indirect costs. Before that, it is necessary to enter the individual categories of indirect costs in production and then the costs of management and sales. Allocating indirect costs per work orders is done by applying the indirect cost scheduling methods and takes place in two stages. The user selects methods for the allocation of indirect costs to calculate the coefficient for the allocation of indirect costs (Habek, 2002). formula 1:

The coefficient for the allocation of indirect costs is calculated according to

$$
\text { Coefficient for allocation of indirect costs }=\frac{\text { allocated indirect costs }}{\text { method for allocating indirect costs }}
$$

Based on the calculated coefficient for the allocation of indirect costs, indirect costs per individual work orders are allocated according to formula 2 :

Coefficient $\mathrm{x}$ cost base WO $1=$ associated indirect cost for WO 1

Coefficient $\mathrm{x}$ cost base WO 2 = associated indirect cost for WO 2

Coefficient $\mathrm{x}$ cost base WO $\mathrm{n}=$ associated indirect cost for WO $\mathrm{n}$

$$
\text { Control: total base allocated indirect costs }
$$

In the first stage, the user according to certain criteria selects methods (0-3) for the allocation of indirect costs per facility (if the company has facilities). Excel then calculates the coefficient for the allocation of indirect costs per individual facilities. 

facility:

The user can select the following methods for allocating indirect costs per

\section{0 - Direct entry}

It is entered when all or some categories of indirect costs are not allocated (e.g. electric power, heating energy, water, overhead) per facilities, but only data is entered into specific sections for each facility. The most common case of using this method is the companies that are composed of dislocated facilities.

\section{1 - Headcount}

It is suitable for the allocation of indirect costs of different types of energy as well as administration and sales costs.

2 - Direct costs

It is suitable for the allocation of all categories of indirect production costs, guided by the logic that work orders with the highest direct costs should assume the largest portion of indirect costs.

\section{3 - Sales value}

It is suitable for allocation of management and sales costs.

In the second stage, the user selects methods (A-G) according to certain criteria for the allocation of indirect costs per work orders. Excel then calculates the coefficient for allocating indirect costs to individual work orders.

The user can choose the following methods for allocating indirect costs per work orders (Habek, 2002):

\section{A-Quantity of base material}

The quantity of base material as basis for allocation of indirect costs can be used if the following conditions are met:

- Material is relatively the most important factor in the production process,

- Materials used are homogeneous, meaning they have a unique unit of measure and approximately the same value per unit,

- There is a real proportional relationship between the costs allocated and the amount of material consumed.

If these conditions do not exist, then the criteria based on the amount of consumed material provide unrealistic results.

\section{$B$ - Number of hours spent in manufacturing}

The number of hours spent on manufacturing as basis for allocation of indirect costs can be used if the following conditions are met:

- Performance of an employee expressed in hours is relatively the most important factor in the production process (labor intensive production),

- Employee qualifications are relatively homogeneous, i.e. there are no major variations in work complexity,

- There is an approximately proportional relationship between the costs allocated and the hours spent on manufacturing.

This method was used in the past for the allocation of indirect costs. However, it usually does not provide good results, as the hours spent on manufacturing often vary depending on the pace of production, while indirect costs flow evenly, so there is a large fluctuation in the association of these costs with products over the period. 


\section{$C-$ Cost of base material}

Cost of base material is one of the very common bases for the allocation of indirect costs and can be used if the following conditions are met:

- Cost of base material is the predominant part of the total cost and they are relatively the most influential factor in the production process,

- Similar materials are used to manufacture all products,

- Indirect costs allocated are relatively proportional to the consumption of materials.

\section{D-Manufacturing cost}

Manufacturing cost as a basis for the allocation of indirect costs can be used if the following conditions are met:

- Manufacturing costs prevail in the structure of total production costs. Production is labor intensive, and the cost of materials is significantly lower than the manufacturing cost,

- Wages of direct manufacturing workers per hour are relatively uniform and evenly distributed by product types,

- There is a correlation between manufacturing costs and indirect costs.

\section{$E-$ Total direct costs}

Total direct costs as a basis for the allocation of indirect costs can be used if the following conditions are met:

- Total direct costs prevail in the structure of total costs,

- There is a high correlation between direct costs and indirect costs.

\section{$F-$ Quantity of produced units}

The quantity of produced units as basis for allocation of indirect costs is one of the simplest methods, but rather not precise. This method is applicable only when large batches of products of a small value and approximately equal value are produced. It is not applicable in the production of unique products and in the production using the system of work orders.

\section{$G$ - Sales value of produced units}

The sales value of the produced units as basis for allocation of indirect costs follows the commercial logic of allocation. The thesis is that products that are commercially more valuable should also accept a higher portion of indirect costs. This method usually has nothing to do with the actual causes of costs, so it is often inappropriate for the allocation of indirect costs but can be used to allocate certain categories of indirect costs for which it is difficult to determine another method.

\subsection{Reduction of direct costs (Step 5)}

The user must first choose between the two options offered: reduction the total direct costs of all work orders or reduction the direct costs of individual work orders. Subsequently, the user selects individual measures and activities for reduction direct costs and enters the amounts of expected reduction of direct costs. Excel then corrects the direct costs and enters them as the estimated cost in the seventh step. The user can select the following measures and activities to reduction direct costs, which are divided into four base groups and presented in Table 1. and relate to the wood industry. The specifics of 
direct costs in the wood industry are large stocks of raw materials and a large number of working hours required for the manufacture of products due to labour-intensive production.

Table 1. Measures and activities to reduction direct cost

\begin{tabular}{|c|c|c|}
\hline No. & COST REDUCTION MEASURES & COST REDUCTION ACTIVITIES \\
\hline \multicolumn{3}{|c|}{ A. COST REDUCTION OF BASE MATERIAL } \\
\hline A.1. & Reduction average stock size & Increase in stock turnover ratio \\
\hline A. 2 . & Reduction the size of security stock & Shortening procurement time \\
\hline A.3. & $\begin{array}{l}\text { Reduction the cost of ordering and } \\
\text { stockpiling }\end{array}$ & Optimizing order size \\
\hline A. 4. & Reduction the size of base material & $\begin{array}{l}\text { Procurement of individual parts for } \\
\text { products in cooperation }\end{array}$ \\
\hline \multirow{2}{*}{ A.5. } & \multirow{2}{*}{$\begin{array}{l}\text { Reduction the size of reject in the } \\
\text { production process }\end{array}$} & Introduction of interfacial control \\
\hline & & Intensification of interfacial control \\
\hline \multicolumn{3}{|c|}{ B. COST REDUCTION OF AUXILIARY MATERIAL } \\
\hline B.1. & $\begin{array}{l}\text { Reduction stock (measures are specified } \\
\text { under items A.1., A.2. and A.3.) }\end{array}$ & $\begin{array}{l}\text { Activities are specified under items A.1., } \\
\text { A.2. and A.3. }\end{array}$ \\
\hline B.2. & $\begin{array}{l}\text { Reduction reject (measure is specified } \\
\text { under item A.5.) }\end{array}$ & Activities are specified under item A.5. \\
\hline \multicolumn{3}{|c|}{ C. COST REDUCTION OF MANUFACTURING } \\
\hline \multirow{3}{*}{ C.1. } & \multirow{3}{*}{$\begin{array}{l}\text { Reduction the amount of manufacturing } \\
\text { by increasing productivity }\end{array}$} & $\begin{array}{l}\text { Determination of production time norms } \\
\text { for each workplace }\end{array}$ \\
\hline & & $\begin{array}{l}\text { Analyzing and correcting production time } \\
\text { norms for each workplace }\end{array}$ \\
\hline & & Making full use of working hours \\
\hline \multirow{2}{*}{ C.2. } & \multirow{2}{*}{$\begin{array}{l}\text { Reduction preparation time by } \\
\text { minimizing idle motion in manufacturing } \\
\text { to a minimum }\end{array}$} & $\begin{array}{l}\text { Servicing workplace with all necessary } \\
\text { resources for production }\end{array}$ \\
\hline & & Shortening of transport routes \\
\hline C.3. & $\begin{array}{l}\text { Reduction the amount of manufacturing } \\
\text { (cooperation) }\end{array}$ & $\begin{array}{l}\text { Procurement of individual parts for } \\
\text { products in cooperation }\end{array}$ \\
\hline C. 4 . & $\begin{array}{l}\text { Reduction the number of errors in the } \\
\text { production process }\end{array}$ & $\begin{array}{l}\text { Enhanced quality monitoring in } \\
\text { manufacturing }\end{array}$ \\
\hline \multirow{2}{*}{ C.5. } & \multirow{2}{*}{$\begin{array}{l}\text { Reduction the amount of reject in the } \\
\text { production process }\end{array}$} & Introduction of intermediate control \\
\hline & & Intensification of intermediate control \\
\hline \multicolumn{3}{|c|}{ D. COST REDUCTION OF COOPERATION } \\
\hline D.1. & $\begin{array}{l}\text { Reduction the quantity of production in } \\
\text { cooperation }\end{array}$ & $\begin{array}{l}\text { Manufacturing individual parts } \\
\text { completely or partly in own company }\end{array}$ \\
\hline
\end{tabular}

Source: created by the author 
When carrying out the procedure for reduction direct costs, it is possible to select only one or several measures, and within such measure one or more activities for reduction direct costs. If the estimated cost price is not equal to or less than the planned cost price, it is possible to repeat the procedure by changing the amount or by other measures and activities for reduction direct costs.

\subsection{Reduction of indirect costs (Step 6)}

Before carrying out the procedure for reduction indirect costs, the user should make a choice between the two options offered: reduction the total indirect costs for the entire company or reduction the indirect costs for the given facility. The same procedure described for reduction the direct costs in the previous step is also performed when reduction the indirect costs, just with different measures and activities. Measures and activities for reduction indirect costs are divided into four main groups, noting that there may be more of them, depending on the industry in which the indirect cost reduction. The measures and activities in Table 2 can be applied in the wood industry, which is specific compared to other industries because of the high consumption of electricity, heat energy and water used for cooking logs.

Table 2. Measures and activities for reduction indirect costs

\begin{tabular}{|c|c|c|}
\hline No. & COST REDUCTION MEASURES & COST REDUCTION ACTIVITIES \\
\hline \multicolumn{3}{|c|}{ A. COST REDUCTION OF MAINTENANCE } \\
\hline A.1. & Reduction the overhead & $\begin{array}{l}\text { Contracting maintenance activities with } \\
\text { specialized companies }\end{array}$ \\
\hline \multicolumn{3}{|c|}{ B. COST REDUCTION OF ELECTRICITY } \\
\hline B.1. & Reduction reactive energy & $\begin{array}{l}\text { Installation of compensation into } \\
\text { substations }\end{array}$ \\
\hline B.2. & Reduction peak load & $\begin{array}{l}\text { Installation of a system for monitoring and } \\
\text { managing peak energy }\end{array}$ \\
\hline B.3. & $\begin{array}{l}\text { Reduction power consumption of electric } \\
\text { motors }\end{array}$ & Installation of frequency converters \\
\hline B.4. & $\begin{array}{l}\text { Reduction electricity consumption of } \\
\text { lighting }\end{array}$ & Installation of LED lighting \\
\hline \multicolumn{3}{|c|}{ C. COST REDUCTION OF HEAT ENERGY } \\
\hline \multirow{4}{*}{ C.1. } & \multirow{4}{*}{ Increasing the degree of boiler operation } & Optimizing combustion \\
\hline & & Boiler cleaning - blowout \\
\hline & & Combustion air heating \\
\hline & & Reduction the number of drive interruptions \\
\hline C.2. & $\begin{array}{l}\text { Regulation of heating of facilities and } \\
\text { buildings }\end{array}$ & Optimal control system \\
\hline C.3. & $\begin{array}{l}\text { Reduction losses on equipment and } \\
\text { pipelines }\end{array}$ & Leak sealing, vane closing, insulation \\
\hline
\end{tabular}




\begin{tabular}{|l|l|l|}
\hline \multicolumn{2}{|c|}{ D. COST REDUCTION OF WATER } \\
\hline \multirow{2}{*}{ D.1. } & $\begin{array}{l}\text { Reduction water losses in water supply } \\
\text { network }\end{array}$ & Installation of pressure reduction valves \\
\cline { 3 - 3 } D.2. & $\begin{array}{l}\text { Reduction the consumption of cooling } \\
\text { water }\end{array}$ & Regular maintenance of installations \\
\hline \multirow{2}{*}{ D.3. } & \multirow{2}{*}{$\begin{array}{l}\text { Reduction the consumption of sanitary } \\
\text { water }\end{array}$} & Regular maintenance of installations \\
\hline & & Closing water outside business hours \\
\cline { 3 - 3 } & & Regular maintenance of sanitary equipment \\
\cline { 3 - 3 } & & Installation of photocells on toilets \\
\hline
\end{tabular}

Source: created by the author

The procedure for reduction indirect costs allows one or more measures to be selected, and within such measure one or more activities for reduction indirect costs. If the estimated cost price is not equal to or less than the planned cost price, it is possible to repeat the procedure by changing the amount or by other measures and activities for reduction indirect costs.

\subsection{Work order calculation (Step 7)}

Unlike the previous steps which require the user to enter most of the required data, in this step Excel enters and calculates all the required data. Work order calculation is a synthesis of all previously entered data. Work order calculation shows the planned and incurred direct and indirect costs, i.e. how much the incurred costs deviate from the planned ones, as well as the projected costs obtained on the basis of reduction of certain categories of direct and indirect costs.

\subsection{Work orders calculation recapitulation (Step 8)}

In the last step, as well as in the previous step, the user is not required to provide additional information. Recapitulation of work order calculation is the final overview of all work orders, and all necessary data and calculations are performed by Excel. In this step, information on the planned, achieved and forecasted cost per unit of product and the total cost price can be found for all work orders in one place. A final piece of information relates to reduction the cost price per unit of product and the total reduction in the cost price for all work orders.

\section{TESTING THE MODEL}

To test all the steps of Direct and Indirect Costs Reduction Model (DICRM-8) in manufacturing companies described in the previous chapter, test data were used on the example of an imaginary Slavonija Hrast company belonging to wood industry. This model was tested by using Microsoft Excel. When programming, care was taken that all 
the data that needed to be entered in the tables were entered only once and in one place, automatically transmitted and entered where necessary. For ease of reference, all rows and columns in the tables are highlighted in different colors, noting that the fields where certain data can be entered are marked with green color.

All steps in DICRM-8 in manufacturing companies can be found in the "Main Menu" shown in Figure 1. In this way, all steps that make up the model are easily accessible from one place.

Figure 1. Main menu

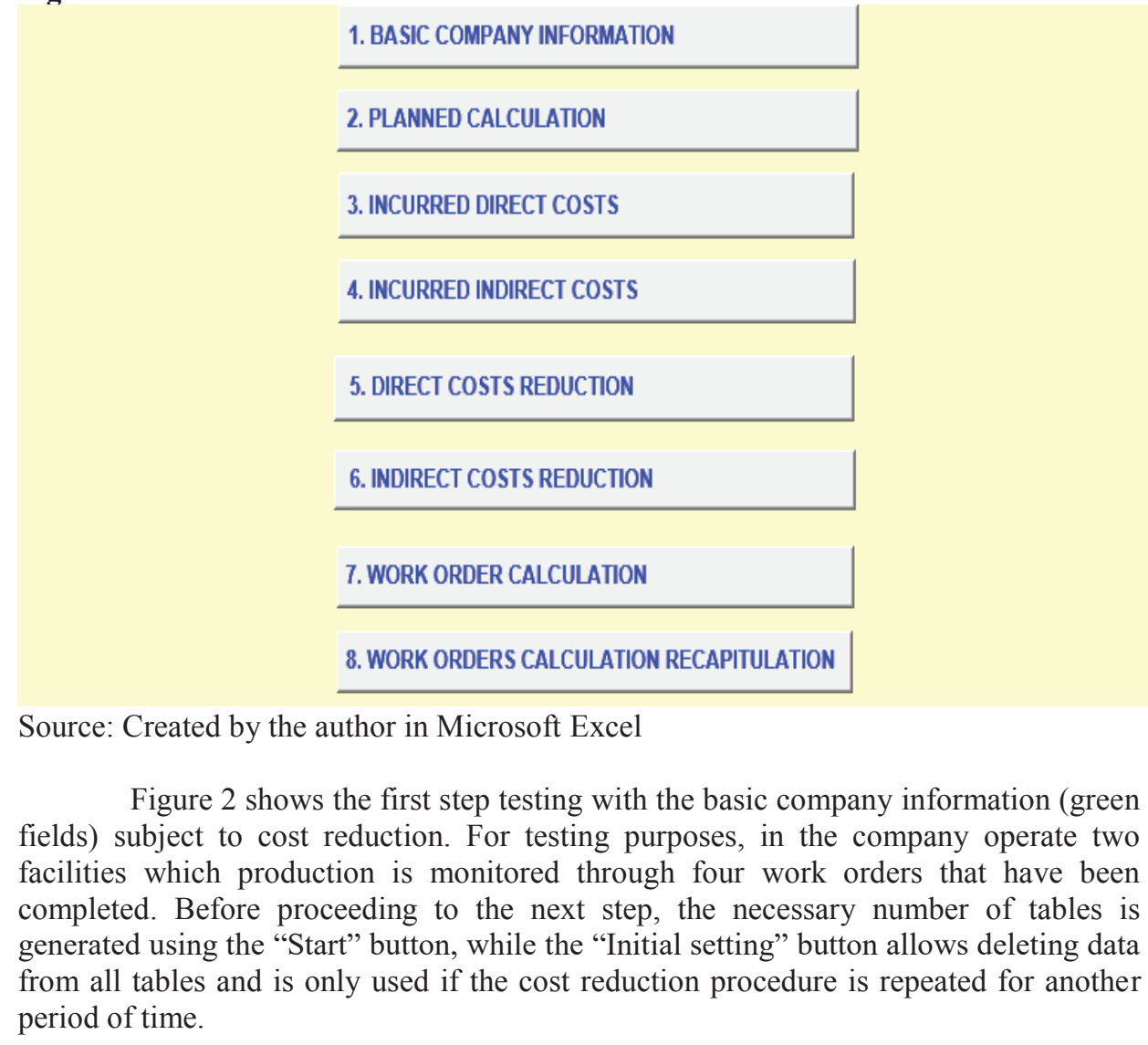


Figure 2. The first step testing - basic company information

\section{COMPANY BASIC INFORMATION}

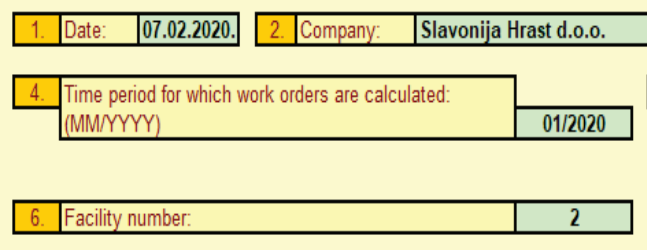

\begin{tabular}{|c|l|c|}
\hline 7. & \multicolumn{2}{|c|}{} \\
\hline No & Facility name & $\begin{array}{c}\text { Number of } \\
\text { workers }\end{array}$ \\
\hline 1 & Furniture production & 80 \\
\hline 2 & Parquet production & 40 \\
\hline \multicolumn{2}{|r|}{ Workers total: } & 120 \\
\hline
\end{tabular}

5. The total number of work orders that relate to the specified time period for the entire company:

4

Source: Created by the author in Microsoft Excel

\begin{tabular}{|c|c|c|c|}
\hline 8. & & & \\
\hline WO mark & No. & Status & Production price per unit \\
\hline $1010 \mathrm{~N}$ & 1 & completed & 310,00 \\
\hline $1020 \mathrm{~N}$ & 2 & completed & $1.000,00$ \\
\hline $2011 \mathrm{P}$ & 3 & completed & 50,00 \\
\hline $0212 \mathrm{P}$ & 4 & completed & 70,00 \\
\hline Initial setting & & START & Menu \\
\hline
\end{tabular}

The second step testing is shown in Figure 3 where the data on planned direct and indirect cost categories are entered in columns 3, 4 and 5, while the program calculates all other data in column 6 . The data entry procedure should be repeated as many times as there are work orders in the production, and in this case it is quadruple. 
Figure 3. The second step testing - planned calculation

Slavonija Hrast d.o.o.

Vinkovci, 07.02.2020.

Facility No.: 1

\section{PLANNED CALCULATION No. 1}

PRODUCT NAME:

CHAIR SH-1

JEDINICA MJERE:

PCS

KOLIČINA:

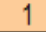

\begin{tabular}{|c|c|c|c|c|c|}
\hline $\begin{array}{l}\text { SEQ. } \\
\text { No. }\end{array}$ & COSTS TYPE AND DESCRIPTION & $\begin{array}{c}\text { MEASUR } \\
\text { EUNIT }\end{array}$ & QUANTITY & $\begin{array}{l}\text { UNIT PRICE } \\
\text { (HRK) }\end{array}$ & TOTAL (HRK) \\
\hline 1 & 2 & 3 & 4 & 5 & 6 \\
\hline 1. & DIRECT COSTS & & & & 181,00 \\
\hline 1.1. & Base material & $\mathrm{m} 3$ & 0,015 & $2.600,00$ & 39,00 \\
\hline 1.2. & Auxiliary material & & 1,000 & 15,00 & 15,00 \\
\hline 1.3 . & Cooperation & & 1,000 & 25,00 & 25,00 \\
\hline 1.4. & Manufacturing work & hour & 4,000 & 25,00 & 100,00 \\
\hline 1.5 . & Other costs & & 1,000 & 2,00 & 2,00 \\
\hline 2. & INDIRECT PRODUCTION COSTS & & & & 71,55 \\
\hline 2.1. & Other materials & & 1,000 & 3,20 & 3,20 \\
\hline 2.2. & Other services & & 1,000 & 1,00 & 1,00 \\
\hline 2.3 . & Overhead & $\mathrm{kWh}$ & 1,000 & 7,50 & 7,50 \\
\hline 2.4. & Electric power & & 50,000 & 0,75 & 37,50 \\
\hline 2.5 . & Heating energy & $\mathrm{m} 3$ & 1,000 & 11,00 & 11,00 \\
\hline 2.6 . & Water & & 0,100 & 7,20 & 0,72 \\
\hline 2.7. & Maintenance & & 1,000 & 1,10 & 1,10 \\
\hline 2.8 . & Amortisation & & 1,000 & 3,53 & 3,53 \\
\hline 2.9 . & Other costs & & 1,000 & 6,00 & 6,00 \\
\hline 3. & PRODUCTION COST (1+2) & & & & 252,55 \\
\hline 4. & MANAGEMENT AND SALES COSTS & & & & 20,00 \\
\hline 5. & COST PRICE $(3+4)$ & & & & 272,55 \\
\hline & $\ll$ Last & & & & $\rightarrow>$ Menu \\
\hline
\end{tabular}

Source: Created by the author in Microsoft Excel

Figure 4 shows the third step testing where data on direct incurred costs for all work orders in columns 5 to 14 are entered and the total achieved direct costs for all work orders are calculated by the program. 
Figure 4. The third step testing of - incurred direct costs Slavonija Hrast d.0.0.

Vinkovci, 07.02.2020.

\section{INCURRED DIRECT COSTS FOR}

\begin{tabular}{|c|c|c|c|c|c|c|c|c|c|c|c|c|c|c|}
\hline \multirow{2}{*}{$\begin{array}{l}\text { SEQ. } \\
\text { No. }\end{array}$} & \multirow{2}{*}{$\begin{array}{l}\text { Work } \\
\text { order } \\
\text { no. }\end{array}$} & \multirow{2}{*}{\begin{tabular}{|l|l|}
$\begin{array}{l}\text { Facilit } \\
\text { y no. }\end{array}$ \\
\end{tabular}} & \multirow{2}{*}{$\begin{array}{l}\text { No. of } \\
\text { plan. } \\
\text { calcul } \\
\text { ations }\end{array}$} & \multirow{2}{*}{$\begin{array}{l}\text { Produced } \\
\text { quantity }\end{array}$} & \multicolumn{3}{|c|}{ BASE MATERIAL } & \multirow{2}{*}{$\begin{array}{c}\text { AUXILIARY MATERIAL } \\
\text { HRK } \\
\end{array}$} & \multirow{2}{*}{$\begin{array}{c}\text { COOPERATION } \\
\text { HRK }\end{array}$} & \multicolumn{3}{|c|}{ MANUFACTURING WORK } & \multirow{2}{*}{$\begin{array}{c}\text { OTHER COSTS } \\
\text { HRK }\end{array}$} & \multirow{2}{*}{$\begin{array}{l}\text { TOTAL DIRECT } \\
\text { COSTS (HRK) }\end{array}$} \\
\hline & & & & & MU & QTY & HRK & & & MU & aTY & HRK & & \\
\hline 1 & 2 & 3 & \begin{tabular}{|l|l}
4 \\
\end{tabular} & 5 & 6 & 7 & 8 & 9 & 10 & 11 & 12 & 13 & 14 & 15 \\
\hline & & & & $6.000,000$ & $\mathrm{~m} 3$ & 100,000 & $280.000,00$ & $90,000,00$ & $150.000,00$ & sat & 27800,0 & $690,000,00$ & $12.000,00$ & $1.202 .000,00$ \\
\hline & 2 & & 2 & $1.000,000$ & $\mathrm{~m} 3$ & 55,000 & $143.000,00$ & $80.000,00$ & $90,000,00$ & sat & 12000,0 & $300.000,00$ & $3.000,00$ & $616.000,00$ \\
\hline & 3 & 2 & & $20.000,000$ & $\mathrm{~m} 3$ & 352,000 & $503.200,00$ & $50.000,00$ & & sat & 5750,0 & $115.000,00$ & & $728.200,00$ \\
\hline 4 & 4 & 2 & & $30.000,000$ & $\mathrm{~m} 3$ & 500,000 & $1.100,000,00$ & $30.000,00$ & & sat & 5170,0 & $103,400,00$ & & $1.233 .400,00$ \\
\hline 5 & & & TOTAL: & $57.000,0000$ & & 1007,000 & $2.086 .200,00$ & $250.000,00$ & $240.000,000$ & & 50520,0. & $1.208 .400,00$ & $15.000,00$ & $3.779 .600,00$ \\
\hline
\end{tabular}

Source: Created by the author in Microsoft Excel

The fourth step testing is shown in Figure 5, where data on the individual categories of incurred indirect costs are entered in columns 3, 4 and 5, and then individual methods (0-3) are selected in column 6 for the allocation of indirect costs per facility. Then, by using the "Distribute costs" button, the program calculated and entered the associated indirect costs for individual facilities into column 7. Subsequently, individual methods (A-G) were selected in column 8 for the allocation of indirect costs per work orders. By using the "Distribute costs" button, the program calculated and entered the associated indirect costs per individual work orders.

Figure 5. The fourth step testing - incurred indirect costs Slavonija Hrast d.0.0.

Vinkovci, 07.02.2020.

\section{INCURRED INDIRECT COSTS FOR}

\begin{tabular}{|c|c|c|c|c|c|c|c|c|c|}
\hline \multirow[b]{2}{*}{$\begin{array}{l}\text { SEQ. } \\
\text { No. }\end{array}$} & \multirow[b]{2}{*}{ COSTS DESCRIPTION } & \multirow{2}{*}{$\begin{array}{l}\text { MEASU } \\
\text { RE } \\
\text { UNIT }\end{array}$} & \multirow[b]{2}{*}{ QUANTITY } & \multirow{2}{*}{$\begin{array}{c}\text { TOTAL AMOUNT } \\
\text { (HRK) }\end{array}$} & \multirow{2}{*}{$\begin{array}{c}\text { FACILITIES } \\
\text { DISTRIBUTII } \\
\text { ON KEY }\end{array}$} & \multicolumn{2}{|c|}{ FACILITY 1} & \multicolumn{2}{|c|}{ FACILITY 2} \\
\hline & & & & & & Amount (HRK) & $\begin{array}{l}\text { Wo } \\
\text { Key }\end{array}$ & Amount (HRK) & $\begin{array}{l}\text { Wo } \\
\text { Key }\end{array}$ \\
\hline 1 & 2 & 3 & 4 & 5 & 6 & 7 & 8 & 7 & 8 \\
\hline 1. & INDIRECT PRODUCTION COSTS & & & $997,027,00$ & & 671.228 .46 & & $325.800,54$ & \\
\hline 1.1. & Other material & & & $41,000,00$ & 0 & $28.000,00$ & D & $13.000,00$ & c \\
\hline 1.2. & Other services & & & $12.500,00$ & 0 & $9.000,00$ & D & $3.500,00$ & c \\
\hline 1.3. & Overhead & & & $118,000,00$ & 0 & $85.000,00$ & D & $53.000,00$ & c \\
\hline 1.4. & Electric power & $\mathrm{kWh}$ & $539.022,000$ & $404.287,00$ & 0 & $388.550,00$ & D & $35.717,00$ & c \\
\hline 1.5. & Heating energy & & & $200.000,00$ & 2 & $99.088,68$ & E & $108.913,32$ & E \\
\hline 1.8. & Water & & & $9.200,00$ & 1 & $6.173,33$ & B & $3.088,67$ & $B$ \\
\hline 1.7. & Maintenanoe & & & $20,000,00$ & 2 & $9.620,07$ & B & $10.379,93$ & $B$ \\
\hline 1.8. & Amortisation & & & $70,000,00$ & 0 & $30.000,00$ & B & $40.000,00$ & $B$ \\
\hline 1.9. & Other costs & & & $118.000,00$ & 2 & $55.798,38$ & E & $80.203,62$ & $E$ \\
\hline 2. & MANAGEMENT AND SALES COSTS & & & $370,000,00$ & 0 & $174.446,31$ & E & $192.449,68$ & E \\
\hline & & Distr & ute costs & & & & & $\rightarrow$ Menu & \\
\hline
\end{tabular}

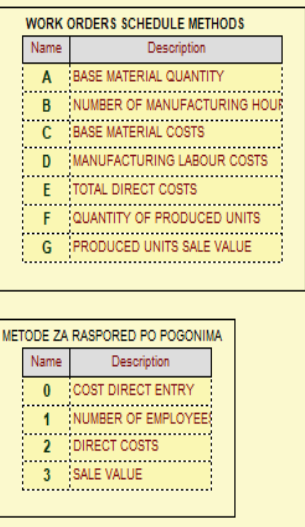

Source: Created by the author in Microsoft Excel 
Before carrying out the procedure for reduction direct costs, it is necessary to compare the incurred direct costs with the planned ones (Main menu, Table 7) and to determine the deviations. The analysis found that the costs of base materials and manufacturing deviated more than $10 \%$ and needed to be reduction. The testing of the fifth step is shown in Figure 6, where direct costs were reduction for all work orders. By selecting measures (column 2) and activity (column 3 ) to reduction costs in column 7 , the amounts of expected direct cost reductions are entered. The total amount of direct cost reduction for each category is calculated by the program and entered in column 11. By using the "Correct costs" button, the program calculated and entered the accompanying reduction of direct costs per individual work orders.

Figure 6. The fifth step testing - direct costs reduction

\begin{tabular}{|c|c|c|c|c|c|c|c|c|c|c|}
\hline \multicolumn{11}{|c|}{ Slavonija Hrast d.o.o. } \\
\hline \multicolumn{2}{|c|}{ Vinkovci, 07.02.2020. } & \multicolumn{4}{|c|}{ 5. DIRECT COSTS REDUCTION } & \multicolumn{5}{|l|}{$01 / 2020$} \\
\hline \multicolumn{2}{|r|}{$\square$ Reduction per given wo } & & & & & \multicolumn{2}{|c|}{ Collect WO costs } & \multicolumn{2}{|l|}{ Correct costs } & $\rightarrow$ Menu \\
\hline \multirow{2}{*}{$\begin{array}{l}\text { SEQ. } \\
\text { No. }\end{array}$} & \multirow{2}{*}{ COSTS REDUCTION MEASURES } & \multirow{2}{*}{ COSTS REDUCTION ACTIVITIES } & \multirow{2}{*}{$\begin{array}{c}\text { TOTAL INCURRED } \\
\text { COSTS }\end{array}$} & \multirow{2}{*}{$\begin{array}{l}\text { wo } \\
\text { No. }\end{array}$} & \multirow{2}{*}{$\begin{array}{c}\text { COSTS PER WORK } \\
\text { ORDER }\end{array}$} & \multicolumn{2}{|c|}{ COSTS REDUCTION } & \multicolumn{2}{|c|}{ COSTS INCREASE } & \multirow{2}{*}{$\begin{array}{c}\text { REDUCED / } \\
\text { INCREASED COSTS }\end{array}$} \\
\hline & & & & & & HRK & $\%$ & HRK & $\%$ & \\
\hline 1 & 2 & 3 & 4 & 5 & 6 & 7 & 8 & 9 & 10 & 11 \\
\hline 1. & BASE MATERIAL & & $2.086 .200,00$ & & & $2220.000,00$ & 10,65 & 0,00 & 0,00 & $1.846 .200,00$ \\
\hline 1.1. & Average stock siee decrease & Increasse in stock tumover ratio & & & & $35.000,000$ & & & & \\
\hline 1.2. & Security stocks size reduction & Procurement time shortening & & & & $25.000,00$ & & & & \\
\hline 1.3. & $\begin{array}{l}\text { Ordeing and stockpiling costs } \\
\text { reseuction }\end{array}$ & Order sice optimisstion & & & & & & & & \\
\hline 1.4. & Base material amount resuction & $\begin{array}{l}\text { Production of individual parts for } \\
\text { cooperative products }\end{array}$ & & & & & & & & \\
\hline 1.5. & Base material amount increase & 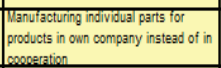 & & & & & & & & \\
\hline 18 & Reducing the amount of reject in the & \begin{tabular}{|l|l|l} 
Introducing intermediate control \\
\end{tabular} & & & & $180,000,00$ & & & & \\
\hline 1.6 & production process & \begin{tabular}{|l|} 
Strengthening intermediate control \\
\end{tabular} & & & & & & & & \\
\hline
\end{tabular}

Source: Created by the author in Microsoft Excel

As for the previous reduction of direct costs and prior to reduction indirect costs, it is necessary to compare the indirect incurred costs with the planned ones (Main Menu, Table 7) and to establish deviations. Electricity costs have been found to deviate by more than $10 \%$ and need to be reduction. Testing the sixth step is shown in Figure 7, where the indirect costs were reduction for all facilities. By selecting the measures (column 2) and the activity (column 3) for reduction costs in column 7, the amounts of expected drop in indirect costs are entered. The total amount of indirect cost reduction for each category is calculated by the program and entered in column 11. By using the "Correct costs" button, the program calculated and entered the accompanying reduction of indirect costs per individual work orders. 
Figure 7. The sixth step testing - indirect costs reduction

\begin{tabular}{|c|c|c|c|c|c|c|c|c|c|c|}
\hline \multicolumn{2}{|c|}{ Vinkovci, 07.02.2020. } & \multicolumn{4}{|c|}{ 6. INDIRECT COSTS REDUCTION } & $01 / 2020$ & & & & \multirow[b]{2}{*}{$\rightarrow$ Menu } \\
\hline & $\square$ Reduction per given facility & Collect facility costs & & & & & \multicolumn{2}{|c|}{ Correct costs } & & \\
\hline \multirow{2}{*}{$\begin{array}{l}\text { SEQ. } \\
\text { No. }\end{array}$} & \multirow{2}{*}{ COSTS REDUCTION MEASURES } & \multirow{2}{*}{ COSTS REDUCTION ACTIVITIES } & \multirow{2}{*}{$\begin{array}{c}\text { TOTAL INCURRED } \\
\text { COSTS }\end{array}$} & \multirow{2}{*}{$\begin{array}{l}\text { No. } \\
\text { Fac. }\end{array}$} & \multirow{2}{*}{$\begin{array}{l}\text { COSTS PER } \\
\text { FACILITY }\end{array}$} & \multicolumn{2}{|c|}{ COSTS REDUCTION } & \multicolumn{2}{|c|}{ COSTS INCREASE } & \multirow{2}{*}{\begin{tabular}{|c|} 
REDUCED / \\
INCREASED COSTS
\end{tabular}} \\
\hline & & & & & & HRK & $\%$ & HRK & $\%$ & \\
\hline 1 & 2 & 3 & 4 & 5 & 6 & 7 & 8 & 9 & 10 & 11 \\
\hline 1. & OVERHEAD & & $118.000,00$ & & & 0,00 & 0,00 & 0,00 & 0,00 & $118.000,00$ \\
\hline 1.1. & Resucing the number of workers & $\begin{array}{l}\text { Waintengances, clasning and guarding } \\
\text { arrangement with specialized } \\
\text { comoanies. }\end{array}$ & & & & & & & & \\
\hline 1.2. & Increasse the number of workers & $\begin{array}{l}\text { Newly purchased equipment handing } \\
\text { and arrangement }\end{array}$ & & & & & & & & \\
\hline \multicolumn{11}{|l|}{1.3 . } \\
\hline 2. & ELECTRIC POWER & & $404,287,00$ & - & & $80.000,00$ & 19,79 & 0,00 & 0,00 & $324.287,00$ \\
\hline 2.1. & Resucing reactive energy & Installing compenssation & & & & & & & & \\
\hline 2.2. & Reducing peak load & $\begin{array}{l}\text { Installation monitoring and peak energy } \\
\text { mangaement system }\end{array}$ & & & & $20.000,00$ & & & & \\
\hline 2.3. & $\begin{array}{l}\text { Reducing power consumption of } \\
\text { electric motors }\end{array}$ & Installation of frequency converters & & & & $50.000,00$ & & & & \\
\hline 2.4. & $\begin{array}{l}\text { Reducing electricity consumption in } \\
\text { lighting }\end{array}$ & | Instalalation of LED lighting & & & & $10.000,00$ & & & & \\
\hline
\end{tabular}

Source: Created by the author in Microsoft Excel

Figure 8 shows the eighth step testing, where no additional data need to be entered, because the program has already calculated and entered all. In the calculation of the work order, all individual categories of direct and indirect costs are obvious. In the columns, costs are allocated in the form of planned costs (columns 3 and 4), incurred costs (columns 5 and 6) and the deviation of incurred costs from planned ones in absolute (columns 7 and 9) and relative amounts (columns 8 and 10), and the forecasted costs (columns 11 and 12) as a result of reduction direct and indirect costs. All the data presented in the columns are given in two forms; first, by unit of product, and second, by work order. The number of calculations corresponds to the number of work orders. 
Figure 8. The seventh step testing - work order calculation

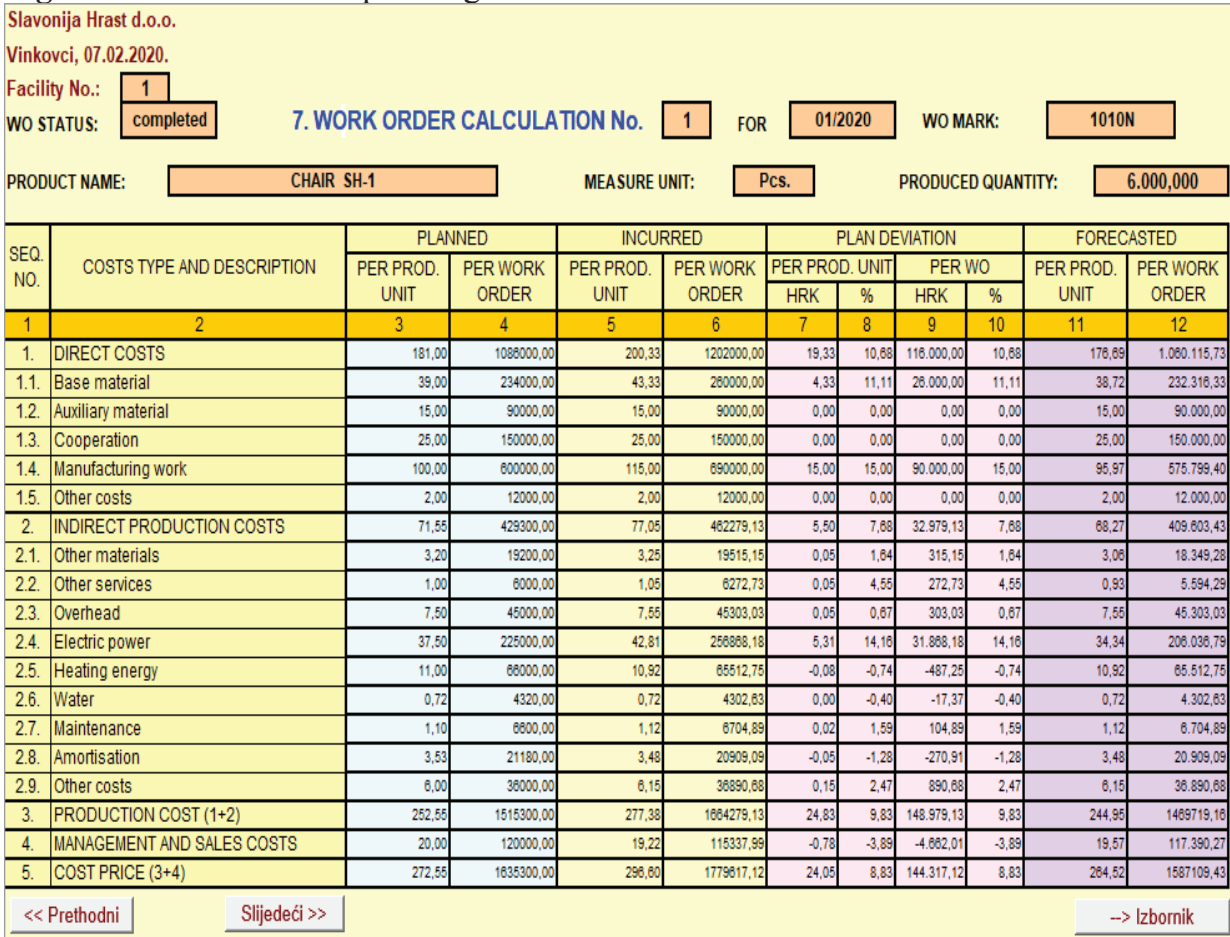

Source: Created by the author in Microsoft Excel

The last eighth step testing is shown in Figure 9, where, as in the previous step, no additional data need to be entered, because the program has already calculated and entered all. The recapitulation of the work order calculation shows the planned cost price (columns 3 and 4), the achieved cost price (columns 5 and 6), the forecasted cost price (columns 7 and 8) and the cost reduction price (columns 9 to 12). The information obtained applies to all work orders and can be found per unit of product and per work order, and the cost reduction is shown in absolute (columns 9 and 11) and relative (columns 10 and 12) amounts. 
Figure 9. The eighth step testing - work order calculation recapitulation

\begin{tabular}{|c|c|c|c|c|c|c|c|c|c|c|c|}
\hline \multirow{2}{*}{\multicolumn{8}{|c|}{$\begin{array}{l}\text { Slavonija Hrast d.o.0. } \\
\text { Vinkovci, 07.02.2020. }\end{array}$}} & \multirow{3}{*}{\multicolumn{2}{|c|}{$01 / 2020$}} & \multirow{3}{*}{\multicolumn{2}{|c|}{$\rightarrow$ Izbornik }} \\
\hline & & & & & & & & & & & \\
\hline \multicolumn{8}{|c|}{ 8. WORK ORDERS CALCULATION RECAPITULATION } & & & & \\
\hline \multirow{3}{*}{$\begin{array}{l}\text { SEQ. } \\
\text { NO. }\end{array}$} & \multirow{3}{*}{$\begin{array}{l}\text { WORK } \\
\text { ORDER } \\
\text { NUMBER }\end{array}$} & \multicolumn{2}{|c|}{ PLANNED COST PRICE } & \multicolumn{2}{|c|}{ ACHIEVED COST PRICE } & \multicolumn{2}{|c|}{ FORECASTED COST PRICE } & \multicolumn{4}{|c|}{ COST REDUCTION PRICE } \\
\hline & & \multirow{2}{*}{$\begin{array}{c}\text { PER PRODUCT } \\
\text { UNIT }\end{array}$} & \multirow{2}{*}{$\begin{array}{c}\text { PER WORK } \\
\text { ORDER }\end{array}$} & \multirow{2}{*}{$\begin{array}{l}\text { PER PRODUCT } \\
\text { UNIT }\end{array}$} & \multirow{2}{*}{$\begin{array}{l}\text { PER WORK } \\
\text { ORDER }\end{array}$} & \multirow{2}{*}{\begin{tabular}{c|} 
PER PRODUCT \\
UNIT
\end{tabular}} & \multirow{2}{*}{$\begin{array}{l}\text { PER WORK } \\
\text { ORDER }\end{array}$} & \multicolumn{2}{|c|}{\begin{tabular}{|l|} 
PER PRODUCT UNIT \\
\end{tabular}} & \multicolumn{2}{|c|}{ PER WORK ORDER } \\
\hline & & & & & & & & HRK & $\%$ & \begin{tabular}{|l|l|} 
HRK \\
\end{tabular} & $\%$ \\
\hline 1 & 2 & 3 & 4 & 5 & 6 & 7 & 8 & 9 & 10 & 11 & 12 \\
\hline 1 & 1 & 272,55 & 1835300,00 & 298,80 & 1779817,12 & 284,52 & 1587109,43 & $-32,08$ & \begin{tabular}{c|c|c|}
-102 \\
\end{tabular} & $-192.507,89$ & $-10,82$ \\
\hline 2 & 2 & 799,72 & 799722,00 & 884,06 & 884055,84 & 797,33 & $\begin{array}{ll}797328,48 \\
\end{array}$ & $-88,73$ & $-9,81$ & $-88.729,18$ & $-9,81$ \\
\hline 3 & 3 & 42,83 & 860084,00 & \begin{tabular}{l|l}
48,27 \\
\end{tabular} & 925463,28 & 42,08 & 841654,70 & $-4,19$ & $-9,06$ & $-83.808,57$ & $-9,08$ \\
\hline 4 & 4 & 47,49 & 1424562,00 & 51,81 & 15543388,93 & 47,03 & 1410759,45 & $-4,79$ & $-9,24$ & $-143.627,49$ & 9,24 \\
\hline \multicolumn{2}{|c|}{ UKUPNO: } & & $4.716 .288,00$ & & $5.143 .522,97$ & & $4.638 .850,04$ & & & $5006.672,93$ & $-9,88$ \\
\hline
\end{tabular}

Source: Created by the author in Microsoft Excel

\section{RESULTS AND DISCUSSION}

The results show that the procedures for reduction direct and indirect cost can be easily, quickly and accurately implemented by using the Direct and Indirect Costs Reduction Model (DICRM-8) in manufacturing companies. Furthermore, it is possible to make multiple simulations of certain measures and activities to reduction direct and indirect costs and to obtain cost estimates based on the simulations performed. All known cost reduction methods describe a cost reduction process without indicating specific cost reduction measures and activities. Unlike cost reduction methods, the mentioned model combines planned costs, incurred costs and projected costs in one place as a result of cost reduction. Therefore, the model can be used in manufacturing companies to reduction direct and indirect costs.

The initial hypotheses set out in this paper were proven through testing all eight steps that make up an integral part of the model. Thus, the example of a manufacturing company shows the comparison of planned and subsequent calculations, and the existence of deviations. Based on these deviations, the procedures were implemented to reduction direct and indirect costs and obtain the estimated price for all work orders. Furthermore, the model made it possible to compare planned, achieved and forecasted cost prices, as well as to calculate the total amount of cost reductions per all work orders. The contribution of the paper is to develop and set up a Direct and Indirect Costs Reduction Model in manufacturing companies, which has not been described like this in the literature so far. Thus, the model connected different activities to allow corrective actions to be taken to ensure that the cost price for an individual product obtained by calculating a work order is equal to or less than the projected cost price for that product.

One of the restrictions of the research is the assumption that all work orders are completed for a month in which they are calculated, although this may not always be the case in manufacturing companies because they may also be not finished. The second restriction relates to administration and sales costs that are immediately allocated to work orders, as well as all other indirect costs of production, assuming that everything produced 
is sold straight away, but not when the product is sold in accordance with International Accounting Standard No. 2 (Narodne Novine, 2009). The measures and activities for reduction direct and indirect costs outlined in the model relate to application in wood industry. Adding new measures and activities for reduction direct and indirect costs for use in other industries and modifying the model itself in terms of extending the number of steps can be considered as a basis for further research in the area of cost reduction. The model can be implemented in the existing information system of the manufacturing company, as follows: in the subsystem of accounting and finance or in the subsystem of controlling with additional costs for adaptation depending on the software manufacturer.

\section{CONCLUSION}

Manufacturing companies that produce two or more products are not able to calculate the cost price for each product without a work order system. The introduction of a work order system into production enables continuous monitoring of production costs and calculating the cost price for all products on a monthly basis. If the incurred cost price exceeds the planned one, and the deviation stretches beyond allowed values, then the management responsible for manufacturing has a serious problem. The aim of the research in this paper was to investigate how this problem can be solved. To solve the problem described, a Direct and Indirect Costs Reduction Model (DICRM-8) in manufacturing companies was developed. The test results of the mentioned model through all eight steps confirmed the initial hypothesis that implementing the Direct and Indirect Costs Reduction Model (DICRM-8) it is possible to efficiently manage direct and indirect costs in manufacturing companies.

The main contribution of this research is the development of the Direct and Indirect Costs Reduction Model DICRM-8 in manufacturing companies, which was created by using Microsoft Excel, thus enabling full functionality and application in manufacturing companies. The advantage of this model is that it brings together in one place the various cost reduction activities that so far have been kept in different records and departments in manufacturing companies. The foregoing research restrictions regarding the status of work orders and the timing of administration and sales costs may be considered negligible as they have little impact. The presented model can be modified and upgraded depending on the interests of individual scientists and experts involved in cost reduction. Given that the model has been tested on information about wood industry, its wider application should definitely be considered in the future.

\section{REFERENCES:}

1. Arminen, H., Kylaheiko, K. and Hujala, M. (2012) Trend breaks in Finnish inventory intensities: a small open economy perspective, International Journal of Logistics Systems and Management, 13 (4), pp. 440-457. 
2. Barbole A. N., Yuvraj D., Nalwade and Santosh D. (2013) Impact of Cost Control and Cost Reduction Techniques on Manufacturing Sector, Indian Streams Research Journal [online], 3 (5), available at: https:/www.academia.edu/30915620/Title_Source_Indian_Streams_Research_J ournal_2230-7850_yr_2013_vol_3_iss 5 [17. October 2020.]

3. Belak, V. et. al. (2009) Računovodstvo proizvodnje. Zagreb: RRiF plus.

4. Belak, V. (1995) Menadžersko računovodstvo. Zagreb: RRiF plus.

5. Castellano, D. et al. (2017) A periodic review policy with quality improvement, setup cost reduction, backorder price discount, and controllable lead time, Production \& Manufacturing Research, 5 (1), pp. 328-350.

6. Dahan, E. et al. (2011) The impact of unit cost reductions on gross profit: Increasing or decreasing returns?, IIMB Management Review, 23 (3), pp. 131-139.

7. Dubynina, S. M. (2020) Search and identification of reserves for reduction costs in industrial enterprises, Bulletin of Zaporizhzhia National University. Economic Sciences, 46 (2), pp. 5-21.

8. Habek, M. et al. (2002) Upravljanje zalihama i skladišno poslovanje. Zagreb: RRiF plus.

9. Huang, C. K. (2010) An integrated inventory model under conditions of order processing cost reduction and permissible delay in payments, Applied Mathematical Modelling, 34 (5), pp. 1352-1359.

10. Jauhari, W. A. et al. (2017) A stochastic periodic review inventory model for vendor-buyer system with setup cost reduction and service-level constraint, Production \& Manufacturing Research, 5 (1), pp. 371-389.

11. Johnsson, S. et al. (2019) Energy savings and greenhouse gas mitigation potential in the Swedish wood industry, Energy [online], 187. available at: https://www.sciencedirect.com/science/article/pii/S0360544219316032 [21. February 2021.]

12. Kuo-Ren, L. et al. (2013) A comprehensive extension of an integrated inventory model with ordering cost reduction and permissible delay in payments, Applied Mathematical Modelling, 37 (7), pp. 4709-4716.

13. Moreira, A. et al. (2018) Cost reduction and quality improvements in the printing industry, Procedia Manufacturing [online], 17. available at: https://doi.org/10.1016/ j.promfg. 2018.10.107 [12. September 2020.]

14. Monden, Y., and Lee, J. (1993) How a Japanese auto maker reductions costs, Management Accounting [online], 75 (2), available at: search.proquest.com/openview/2ada8b3afb35b5df554a079922d9b087/1?pqorigsite $=$ gscholar\&cbl $=48426$ [26. October 2020.]

15. Narodne Novine (2009) Međunarodni standardi financijskog izvještavanja, Zagreb: Narodne Novine d.d., 136 (1), pp. 1-304.

16. Pereira, P. (2001) Market power, cost reduction and consumer search, International Journal of Industrial Organization, 19 (9), pp. 1457-1473.

17. Salim, R., Johansson, J. (2018) Automation decisions in investment projects: A study in the Swedish wood products industry, Procedia Manufacturing [online], 25 . available at: 
https://www.sciencedirect.com/science/article/pii/S2351978918306000

$[10$.

February 2021.]

18. Spence M. (1986) Cost Reduction, Competition and Industry Performance, U: Stiglitz J.E. and Mathewson G.F. (eds)., New Developments in the Analysis of Market Structure, International Economic Association Series. London: Palgrave Macmillan. pp. 475-518

19. Shields, M. et al. (1992) Effective long-term cost reduction: A strategic perspective, Journal of Cost Management, 6 (1), pp. 16-30.

20. Soundararajan, K. et al. (2019) Cost-reduction and quality improvement using DMAIC in the SMEs, International Journal of Productivity and Performance Management, 68 (8), pp. 1528-1540.

21. Susto, G. A. et al. (2018) A Dynamic Sampling Approach for Cost Reduction in Semiconductor Manufacturing Procedia Manufacturing [online], 17. available at: https://doi.org/10.1016/j.promfg.2018.10.083 [5. September 2020.]

22. Todorut, A. V. et al. (2016) Sustainable cost reduction by lean management in metallurgical processes, Metalurgija, 55 (4), pp. 846-848. 


\title{
DOPRINOS RAZVOJU MODELA ZA SMANJIVANJE DIREKTNIH I INDIREKTNIH TROŠKOVA (MSDIT-8) U PROIZVODNIM TVRTKAMA
}

\author{
Berislav Bolfek
}

\begin{abstract}
Sažetak
Za smanjivanje troškova postoje brojne metode opisane u literaturi koje objašnjavaju na koji je način moguće smanjivati pojedine vrste troškova. Većina metoda koje se spominju u literaturi ne navodi konkretne mjere $i$ aktivnosti za smanjivanje troškova. U proizvodnim tvrtkama problem nastaje kada je ostvarena cijena koštanja pojedinog proizvoda dobivena obračunom radnog naloga veća od planske cijene tog proizvoda. Cilj istraživanja je pronaći jedan od načina za rješavanje spomenutog problema pomoću smanjivanja direktnih i indirektnih troškova. Metodologija se temelji na razvoju i postavljanju Modela za smanjivanje direktnih i indirektnih troškova (MSDIT8) u proizvodnim tvrtkama koji se sastoji od osam međusobno povezanih koraka. Rezultati testiranja prikazuju punu funkcionalnost navedenog modela koji je omogućio na jednom mjestu uspoređivanje planirane, ostvarene $i$ prognozirane cijene koštanja kao $i$ izračunavanje ukupnog iznosa smanjivanja troškova po svim radnim nalozima. Ključni rezultati prikazuju korištenje različitih mjera $i$ aktivnosti za smanjivanje troškova na primjeru drvne industrije. Ovo istraživanje predstavlja prilog razvoju modela za smanjivanje direktnih i indirektnih troškova u proizvodnim tvrtkama.
\end{abstract}

Ključne riječi: direktni troškovi; indirektni troškovi; smanjivanje troškova; proizvodne tvrtke; DICRM-8. 